\title{
The Contribution of Foreign Direct Investment (FDI) To Domestic Employment Levels in South Africa:
} A Vector Autoregressive Approach

\author{
Bongumusa Prince Makhoba, Irrshad Kaseeram \\ University of Zululand, KwaDlangezwa Campus, Faculty of Commerce, South Africa \\ makhobabp@gmail.com, kaseerami@unizulu
}

\begin{abstract}
Several empirical works have yielded mixed and controversial results with regard to the effects of FDI on employment and economic growth. The primary focus of this study is to investigate the contribution of FDI to domestic employment levels in the context of the South African economy. The analyses of the study were carried out using the annual time series data from 1980 to 2015. The macroeconomic variables employed in the empirical investigation include employment, FDI, GDP, inflation, trade openness and unit labour costs. The study used secondary data from the South African Reserve Bank and Statistics South Africa database. The study estimated a Vector Autoregressive/ Vector Error Correction Mechanism (VAR/VECM) approach to conduct empirical analysis. However, the study also employed single equation estimation techniques, including the Ordinary Least Squares (OLS), Fully Modified Ordinary Least Squares (FMOLS), Dynamic Ordinary Least Squares (DOLS) and Canonical Cointegrating Regression (CCR) models as supporting tools to verify the VAR/VECM results. This study provides strong evidence of a significant negative relationship between FDI and employment levels in the South African economy. Empirical analysis of the study suggests that the effect of economic growth on employment is highly positive and significant in South Africa's economy. The study recommends that policymakers ought to invest more in productive sectors that aim to promote economic growth and development to boost employment opportunities in South Africa.
\end{abstract}

Keywords: Foreign Direct Investment, Employment, and Economic growth.

\section{Introduction}

Over the years, foreign direct investment (FDI), flowing to developing nations from the rest of the world has been widely recognised as a significant, positive contributor to economic growth and development through job opportunities and technological transfer. The present study is aimed at extending and deepening analysis on the contribution of FDI towards domestic employment levels in the South African economy. Several studies indicate that FDI has played a very important role in promoting South Africa's economic growth and job creation. FDI serves as the source of expansion for business opportunities, provide employment opportunities and also increases the level of income for local citizens in the host country. FDI is the flow of capital from an investor's country to an enterprise operating outside of the investor's country (Huang and Ren, 2013 and Tshepo, 2014). Foreign investors are keen to invest in South Africa due to favorable economic conditions, which include many facets that are very attractive to FDI. These include access to natural resources, quality infrastructure, well-developed financial markets, trade openness, and economic and political stability. The general economic argument of FDI states that inward FDI promotes growth and enhances employment levels.

Most studies, which include Mpanju, (2012); Carp, (2012); Huang and Ren, (2013) and Tshepo, (2014) reveal that FDI effect on employment and economic growth has been favorable in most developing nations. In contrast to this, some researchers, such as Jenkins (2006), Bailey and Driffield (2007), Pinn et al. (2011), Wei (2013) and Onimisi (2014), among others, found an inverse relationship between FDI and employment levels. Some researchers, Inekwe, (2013), Wei, (2013) and Okoro and Johnson (2014), suggested that the FDI impact on growth and employment differs across different economic sectors. According to a report published by the Department of Trade and Industry (DTI) (2015), Foreign Direct Investment (FDI) from the developing world predominantly goes to South Africa, North Africa, and oil-exporting countries. The report further stated that a total of 1344 FDI projects were recorded from January 2003 to July 2015 in the South African economy. These FDI projects saw the South African economy recording a total capital investment of US $\$ 71.2$ billion during this period. A total of 189724 jobs were created as a result of these FDI projects. The main FDI sources for South Africa include, among others, the United Kingdom (UK), United States of America (USA), Germany, Australia, and India. Conversely, South African FDI outflows mainly go to the following top five destination countries: United Kingdom, Nigeria, Ghana, Zambia and the United States of America. 
The top five sectors targeted by foreign investors were metals and coal, oil and natural gas, food and tobacco, consumer products and communication services. South Africa has consistently been able to maintain its position as both the top FDI destination in Africa and a prolific FDI investor in the African continent (Department of Trade and Industry, 2015). However, FDI may also have detrimental effects on the economy of the host nation. Pinn et al. (2011) asserted that FDI can affect employment levels in three different scenarios. Firstly, inward FDI creates job opportunities directly through the establishment of new businesses. Secondly, FDI can maintain employment level by acquiring existing firms. Lastly, FDI can decrease employment levels by withdrawing investments and shutting down local firms through intense competition (Pinn et al., 2011). Jenkins (2006) suggested that in cases where FDI involves the acquisition of domestic firms instead of establishing new enterprises, domestic employment levels will stay the same, and if the foreign investor rationalises the firm, employment levels are even more likely to decrease. Furthermore, the employment opportunities that created by FDI tends to favor relatively skilled labour in capital-intensive industries, rather than labour-intensive firms with unskilled labour, which is oversupplied in the South African labour market (Jenkins, 2006, also cited by Makino and Tsang, 2011).

The primary purpose of the study is to probe the subject matter by using econometric analyses to further investigate the contribution of FDI to employment in South Africa from the period 1980-2015 by drawing on data from employment, FDI, Gross Domestic Product (GDP), inflation, trade openness, and unit labour costs. The study attempts to discover this nexus using a VAR/VECM model framework with the annual time series data extracted from the South African Reserve Bank (SARB) and Statistics South Africa (StatsSA) database. The organisation of this paper consists of five sections. Section 1 introduces the paper with a clear background. Section 2 discusses both theoretical and empirical literature on the link between FDI, employment and economic growth. Section 3 gives the discussion of the methodological framework and estimation procedures applicable to conducting an empirical investigation. Section 4 deals with the presentation and discussion of the empirical findings. Finally, section 5 concludes the paper with some policy prescriptions.

\section{Theoretical and Empirical Perspectives}

Theoretical Literature: The FDI-led growth hypothesis is based on endogenous growth theory (Romer, 1994) which stipulates that FDI is strongly associated with human capital, exports, technological and knowledge transfer, and capital flows. These factors significantly stimulate economic growth through FDI inflows (Sunde, 2017). In such instances, the economy is more likely to enjoy the spill-over-effects of knowledge and technology provided by foreign firms (Shakar and Aslam, 2015). These spill-over-effects will bring about improvement and progress in the level of productivity, which will eventually lead to an increase in economic growth. The theory of the capital market is the oldest theory of FDI developed in the 1960s. The capital market theory claims that FDI is mainly determined by the interest rates of the country (Das, 2007). Basically, this theory alludes to three different positions by which FDI is attracted in developing countries. The first one is that undervalued exchange rate ensures that host countries operate under lower production costs. Secondly, long-term investment in developing countries depends more on FDI than the purchase of securities in the stock market.

Since there are no organised securities in existence in the majority of developing countries the third and last position is that FDI allows control of a host country's assets where there is limited information about securities in that nation (Das, 2007). Ricardo (1821) formulated a jobless growth theory which states that there is a negative relationship between investment, output expansion and job creation because capital investment is a perfect substitute for labour in the economy. Vernon (1966) proposed the production cycle theory in order to explain FDI flows from the USA to Western Europe companies in the manufacturing industry. This theory asserts that there are four stages in the product cycle: innovation, growth, maturity, and decline (Denisia, 2010). The life cycle theory may be used to analyse the relationship between the life cycle of a product and potential FDI flows. In the innovation stage, foreign firms produce new, unique products for the domestic market and export the surplus in the foreign markets. This theory asserts that FDI flows are mostly observed in the maturity and declining stage (Denisia, 2010). The findings reveal that there is a negative and insignificant effect of FDI on employment creation in the Chinese economy.

Empirical Literature: This section provides discussions on the body of literature underpinning the link between FDI employment and economic growth in South Africa and from the rest of the word. Numerous 
empirical studies have systematically evaluated the FDI effect on employment and economic growth from the global context; however very few studies have evaluated this relationship from the South African perspective. The empirical findings of recent studies have shown mixed and sometimes controversial (i.e. the impact of FDI differs across different sectors of the economy) results on this relationship. Hence this paper attempt to fill that gap and provide more empirical evidence from the South African perspective. Huang and Ren (2013) investigated the effect of Chinese investment on employment generation in the South African economy. The study used a survey from 16 Chinese enterprises located in Johannesburg to assess their impact on employment generation in the South African economy. The findings of the study indicate that Chinese firms increase job opportunities for both skilled and unskilled workers in South Africa. They emphasised on the importance of improving the investment enabling environment in order to expand the significant positive impact of Chinese firms on employment and growth of the country's economy.

The findings of the survey also suggest that strict labour laws and influential trade unions are important parties that ensure the employment quality of FOEs meets the legal requirements of the country. Wei, (2013) tested the impact of FDI on employment levels using annual time series data from 1985-2011 in China. The results also indicate that the effect of FDI on employment differs across different economic sectors. The impact of FDI on employment was found positive in the primary sector. The secondary sector of the economy exhibited an insignificant and negative effect of FDI on employment, although GDP had a strong positive impact on employment levels. FDI inflows were found negative and significant to promote employment creation while GDP had a positive impact on employment in the tertiary sector. A study conducted by Tshepo (2014) assessed the FDI impact on growth and employment from 1990 to 2013 in South Africa. The study employed the Johansen Co-integration test to assess the long-run co-integrating relationship among variables. The empirical results indicate a positive long-run relationship between FDI, GDP, and employment in the South African economy. The findings also suggest that FDI is an important aspect that stimulates growth and employment levels in the economy of South Africa.

Furthermore, the study suggested that human capital, return on investment, labour cost, labour disputes, and corruption are important factors that influence inward FDI in the South African economy. The study recommends that the South African government ought to deal with these factors to make the country a conducive, environment for FDI to take place. Onimisi (2014) examine the FDI effect on employment generation in Nigeria from 2002-2012. The results indicate a negative effect of FDI on employment, while GDP and interest rate are positively correlated with the employment levels. However, none of the explanatory variables were found significantly to affect employment levels in Nigeria. The study suggests that a negative effect of FDI on employment levels calls for a critical examination of these variables because FDI are recognised to bring about a significant, positive effect on GDP and therefore it is also expected that FDI will bring a reduction in the rate of unemployment in the country. Khatodia and Dhankar (2016) assess the growth of employment in both public and private sector by foreign capital flows which include FDI, Foreign Portfolio Investment (FPI), External Commercial Borrowings (ECBs), and NRI Deposits in India from 1991-2012.

\section{Methodological Framework}

This section presents the methodology and estimation procedure that is employed for the empirical investigation to the link between FDI, employment and economic growth in South Africa. The study is using an annual time series data running from the period of 1980-2015 thus giving us 36 observations, with the following variables: employment, FDI, GDP, inflation, trade openness, and labour costs. All variables in monetary values are measured in terms of domestic currency, i.e. South African Rand. The time series data of all variables are extracted from the South African Reserve Bank (SARB) (www.resbank.co.za) and Statistics South Africa (StasSA) database (http://www.statssa.co.za). The study uses eviews 9 statistical software package for the purpose of analysing data, and empirical estimation and analysis. The data series of variables that are in monetary values were transformed into natural logarithms. The unit roots test results reveal that all variables are integrated of order one, however, the results of unit roots tests are not reported due to brevity but available upon request from the authors.

The VAR/VECM Approach: The study adopts a VAR approach proposed by Sims (1980) to assess dynamic relationships between FDI, economic growth and employment in South Africa. The VAR/VECM is able to trace 
the response of the endogenous variable due to the shocks of other endogenous variables and its own shocks through the impulse response functions (IRF). The VAR/VECM approach can deal with the problem of multicointegration through Johansen cointegration test, unlike the single-equation cointegration test. This approach is considered as more advanced estimation technique due to its ability to differentiate the long-run relationships that are consistent with the short-run dynamic adjustments between the variables (Brooks, 2014). The VECM is important to a VAR framework because of its ability to embed an ECM term in the model. The VAR/VECM is only estimated using three variables in the model due to plausible results and consistency with economic theory, however, the six variables of the model specification are only utilised in the estimation of single equation methods, since they produce plausible results in this regard. As previously mentioned, the short-run dynamics between FDI, employment and economic growth in the system will be assessed through the use of the following VAR model:

$\operatorname{In} Y_{t}=\alpha_{0}+\sum_{i=1}^{p} \Gamma_{i} \operatorname{In} Y_{t-i}+\varepsilon_{t}$

The above equation (1) represents a VAR, where $Y_{t}=E M P_{t}, F D I_{t}, G D P_{t}$ is a $(3 \times 1)$ column vector of three endogenous variables, i.e. employment, FDI and GDP. $\alpha_{0}$ Denotes a $(3 \times 1)$ vector of the constants, $\Gamma_{i}$ is a $(3 \times 3)$ matrix of autoregressive coefficients regressors, $p$ represents the order of VAR and the $\varepsilon_{t}$ vector comprises composites of random shocks in the system. The cointegrating VAR equation will be converted into a VECM equation in order to apply the Johansen VECM methodology. Therefore, the VECM model is estimated to determine the long-run cointegrating relationship between FDI, economic growth and employment. Brooks (2014) asserts that VECM is an appropriate model that captures the long-run and short-run dynamic relationships among variables in the model. In this particular study, the VECM captures the long-run cointegrating relationship between employment, FDI and GDP, as well as the short-run dynamics that are consistent with the long-run equilibrium. The VECM equation can be presented as follows:

$\Delta \operatorname{In} Y_{t}=\alpha_{0}+\Pi \operatorname{In} Y_{t-1}+\sum_{i=1}^{p-1} \Gamma_{i} \Delta \operatorname{In} Y_{t-i}+\varepsilon_{t}$

Where, $\operatorname{In} Y_{t}$ denote $k \times 1$ vector of I(1) variables, $\alpha_{0}$ is the coefficient of intercept, $\Pi$ represents $k \times k$ long-run multiplier matrix and $\Gamma_{i}$ represents $k \times k$ short-run coefficient matrices. The notation of $p$ represents the order of VAR. $\varepsilon_{t}$ Represent innovations in the model. The VECM ( $\Pi y_{t-1}$ term) from the above equation can be expanded as follows:

$\Pi y_{t-1}=\left[\begin{array}{l}\alpha_{11} \\ \alpha_{21} \\ \alpha_{31}\end{array}\right]\left(\begin{array}{lll}\beta_{11} & \beta_{12} & \beta_{13}\end{array}\right)\left[\begin{array}{c}\text { lemp } \\ \text { lfdi } \\ l g d p\end{array}\right]_{t-1}$

From the above equation (3), $\beta_{11}$ represent a normalized equation. $\beta_{12}$, is the long-run elasticity coefficient for employment with respect to the effect of FDI on employment levels. $\beta_{13}$, is the long-run elasticity of employment with respect to the effect of GDP on employment levels. The short-run adjustment coefficients that will be considered in this particular study can be expressed in the following ECM:

$\varepsilon=\left(\operatorname{lemp}-\beta_{12} f d i-\beta_{13} g d p\right)_{t-1}$

From the above equation (4), let assume that employment levels increase by more than its cointegrating relationship in the previous period while FDI and GDP remain dictates, in the following period some or both variables will have to adjust in order to restore the long-run equilibrium relationship. The adjustment coefficient is therefore expected that $\alpha_{11}<0$ since employment must decrease in the current period in order to restore the long-run equilibrium, while FDI and GDP must increase in the following period to adjust this long-run equilibrium relationship, i.e., $\alpha_{21}>0$ and $\alpha_{31}>0$.

The Single Equation Methods: This section gives a discussion of single equation models which include OLS, FMOLS, DOLS, and CCR since these models are employed as supporting and confirmatory models of a VAR/VECM approach. As mentioned earlier, all single equation models are estimated using all six variables in the model specification due to plausible results and consistency with the economic literature. 
Ordinary Least Squares (OLS) Model Estimation: The Ordinary least squares (OLS) regression is a linear estimation technique that can be employed to test for a single response variable recorded on an interval scale. The natural logarithmic presentation of variables in the OLS model with multiple explanatory variables as of this study can be written in the following form:

$\Delta I n E M P_{t}=\alpha_{0}+\beta_{1} I_{n F D I_{1}}+\beta_{2} \operatorname{InGDP}_{2}+\beta_{3} I N F_{3}+\beta_{4} T O P_{4}+\beta_{5} \operatorname{InLC} C_{5}+\varepsilon_{t}$

Where, $\triangle I n E M P_{t}$ is a first differenced dependent variable, followed by stationary explanatory variables which include $I n F D I_{1}, I n G D P_{2}, I N F_{3}, T O P_{4}, I n L C_{5} . \alpha_{0}$ is the constant coefficients, and $\varepsilon_{t}$ is the error term. The logarithmic transformation was carried out only on variables with data on monetary values and indexes, i.e. employment, FDI, GDP and unit labour costs. The data of inflation and trade openness was already in percentage form hence they were not transformed into natural logarithm because they can be interpreted as elasticities.

Fully Modified Ordinary Least Squares (FMOLS) Model: The FMOLS model involves adjusting OLS long-run estimates in such a way that we overcome any form of biasness owing to serial correlation and endogeneity problems in OLS residuals (Phillips and Hansen, 1990 and Harris and Sollis, 2003). Consider the following $\left(Y_{t}, X_{t}^{\prime}\right)$ vector process:

$Y_{t}=X_{t}^{\prime} \beta+D_{t}^{\prime} \gamma_{1}+\varepsilon_{1 t}$

From the above equation (6), $Y_{t}$ represents the dependent I(1) variable. $X_{t}$ is a stochastic regressor as governed by $X_{t}=\Gamma_{21}^{\prime} D_{1 t}+\Gamma_{22}^{\prime} D_{2 t}+\varepsilon_{2 t}$. Furthermore, $D=D_{1 t}^{\prime}, D_{2 t}^{\prime}$ represents the deterministic trend of regressors and $\varepsilon_{1 t}$ is the error term with a zero mean and covariance $(\Omega)$. Therefore, the FMOLS can be presented as follows:

$\hat{\theta}_{F M O L S}=\left[\begin{array}{l}\hat{\beta} \\ \hat{\gamma}_{1}\end{array}\right]=\left[\sum_{t=1}^{T} Z_{t} Z_{t}^{\prime}\right]^{-1}\left[\sum_{t=1}^{T} Z_{t} Y_{t}^{+}-T\left[\begin{array}{c}\hat{\lambda} 12 \\ 0\end{array}\right]\right]$

Equation (7) $Z_{t}=\left(X_{t}^{\prime} D_{t}^{\prime}\right)^{\prime}$ and $Y_{t}^{+}=Y_{t}-\widehat{\omega}_{12} \widehat{\Omega}_{22}^{-1} \hat{\varepsilon}_{2}$ indicates transformed data. $\hat{\lambda}_{12}^{+}=\widehat{\omega}_{12} \hat{\Omega}_{22}^{-1} \widehat{\Lambda}_{22}$ represents the estimated bias correction term with the long-run covariance matrices $\hat{\Omega}$ and $\hat{\Lambda}$ and their respective elements that are computed through the use of $\varepsilon_{t}=\left(\hat{\varepsilon}_{1 t}^{\prime}, \hat{\varepsilon}_{2 t}^{\prime}\right)^{\prime}$.

Dynamic Ordinary Least Squares (DOLS) Model: DOLS is a parametric model which clearly estimates the lagged first difference regressors (Saayman, 2010). This model suggests that the added value of lags $(q)$ and leads $(q)$ of $\Delta X_{t}$ reduces the long-run correlation between error terms ( $\varepsilon_{1 t}$ and $\varepsilon_{2 t}$ ) (Belke and Czudaj, 2010). The leads and lags of $\Delta X_{t}$ eliminate asymptotically any possible biasness due to endogeneity or serial correlation. The DOLS presentation can be written as follows:

$Y_{t}=X_{t}^{\prime} \beta+D_{t}^{\prime} \gamma_{1}+\sum_{j=-q}^{r} \Delta X_{t+j}^{\prime} \delta+\varepsilon_{1 t}$

Where the DOLS estimator is given by $\hat{\theta}_{D O L S}=\left(\hat{\beta}^{\prime}, \hat{\gamma}_{1}^{\prime}\right)^{\prime}$ the number of leads and lags will be selected using the Akaike information criterion (AIC). Stock and Watson (1993) suggest that DOLS is more robust in data series with small observations as compared to other alternative long-run estimators, including models proposed by Engle and Granger (1987), Johansen (1991) and Phillips and Hansen (1990).

Canonical Cointegrating Regressions (CCR) Model: The CCR model transforms variables into a cointegrating regression that removes the second-order bias of the OLS estimator. The transformation of variables has the ability to eliminate endogeneity caused by the long-run correlation of $Y_{1 t}$ and $Y_{2 t}$ (Montalvo, 1995). From equation (6), the CCR presentation can be written as follows:

$\hat{\theta}_{C C R}=\left[\begin{array}{l}\hat{\beta} \\ \hat{\gamma}_{1}\end{array}\right]=\left[\sum_{t=1}^{T} Z_{t}^{*} Z_{t}^{*^{\prime}}\right]^{-1} \sum_{t=1}^{T} Z_{t}^{*} Y_{t}^{*}$

From equation (9), $Z_{t}^{*}=\left(X_{t}^{*^{\prime}}, D_{t}^{\prime}\right)^{\prime}, X_{t}^{t}=X_{t}-\left(\widehat{\Sigma}^{-1} \widehat{\Lambda}_{2}\right)^{\prime} \hat{\varepsilon}_{t}$ and $Y_{t}^{*}=Y_{t}-\left[\widehat{\Sigma}^{-1} \widehat{\Lambda}_{2} \widetilde{\beta}+\left[\begin{array}{c}0 \\ \hat{\Omega}_{22}^{-1} \widehat{\omega}_{21}\end{array}\right]{ }^{\prime} \varepsilon_{t}\right.$ represents the transformed data. The coefficient of $\tilde{\beta}$ represents the estimates of the cointegrating equation that uses static OLS $\widehat{\Lambda}_{2}$ is the second column of $\widehat{\Lambda}$ and $\widehat{\Sigma}$ is the estimated contemporaneous covariance matrix of error terms. Montalvo (1995) asserted that CCR is similar to the FMOLS estimator, except that FMOLS only transforms the endogenous variable and corrects the OLS estimates in the regression of the modified $Y_{1 t}$. 


\section{Empirical Results and Analysis}

The study utilises two unit root tests to determine if variables are stationary or not and analyse the integration properties of data through the Augmented Dickey-Fuller and Phillips Perron Tests. The graphical analysis of the data series in level form revealed that data series of almost every variable is non-stationary, however, after converting these variables into the first difference, the series became stationary, i.e., I(1). The unit root results are not presented in this paper but available upon request from the author(s). Asterio and Hall (2016) assert that determining the order of integration is extremely important as one proceeds to estimate cointegration test.

Table 1: Summary of Cointegrating Test Assumptions

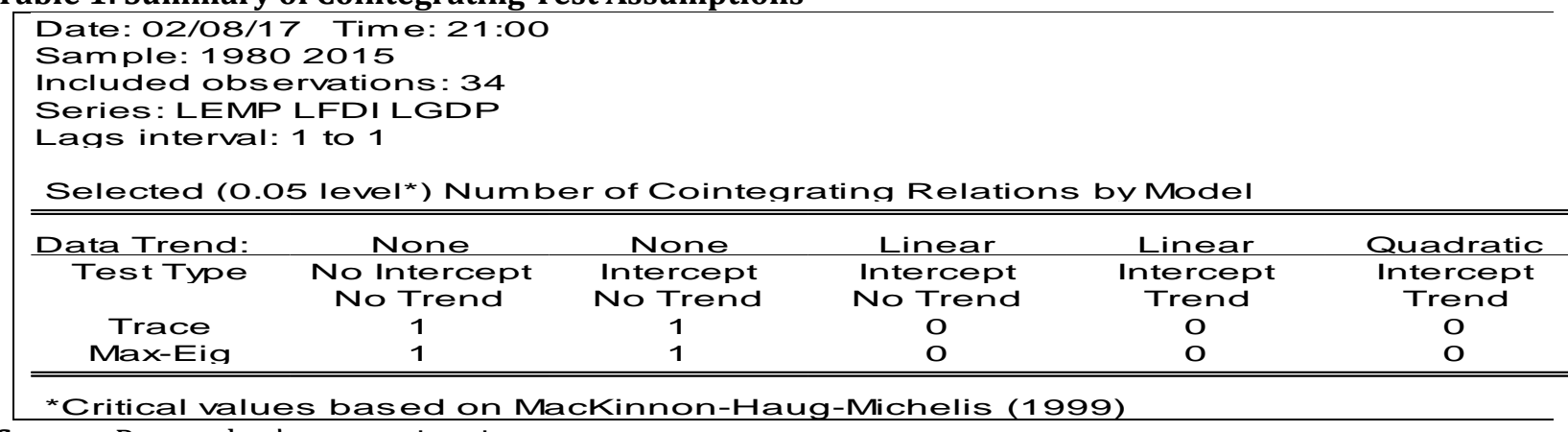

Source: Researcher's own estimations.

Table 1, shows five different assumptions that can be chosen with regard to the possible cointegration among the variables. The results show that cases 1 and 2 indicate that only one cointegrating relationship exists among the variables. However, in practice cases 1 and 5 are not plausible for macroeconomic time series data analysis. While case 3, 4 and 5 indicates no sign of cointegration. Therefore, case 2 provides stronger support for cointegration since both the trace and maximum statistics confirm one cointegrating relationship. Hence, the study proceeds to estimate a cointegration based on case 2 .

Table 2: Cointegration Results

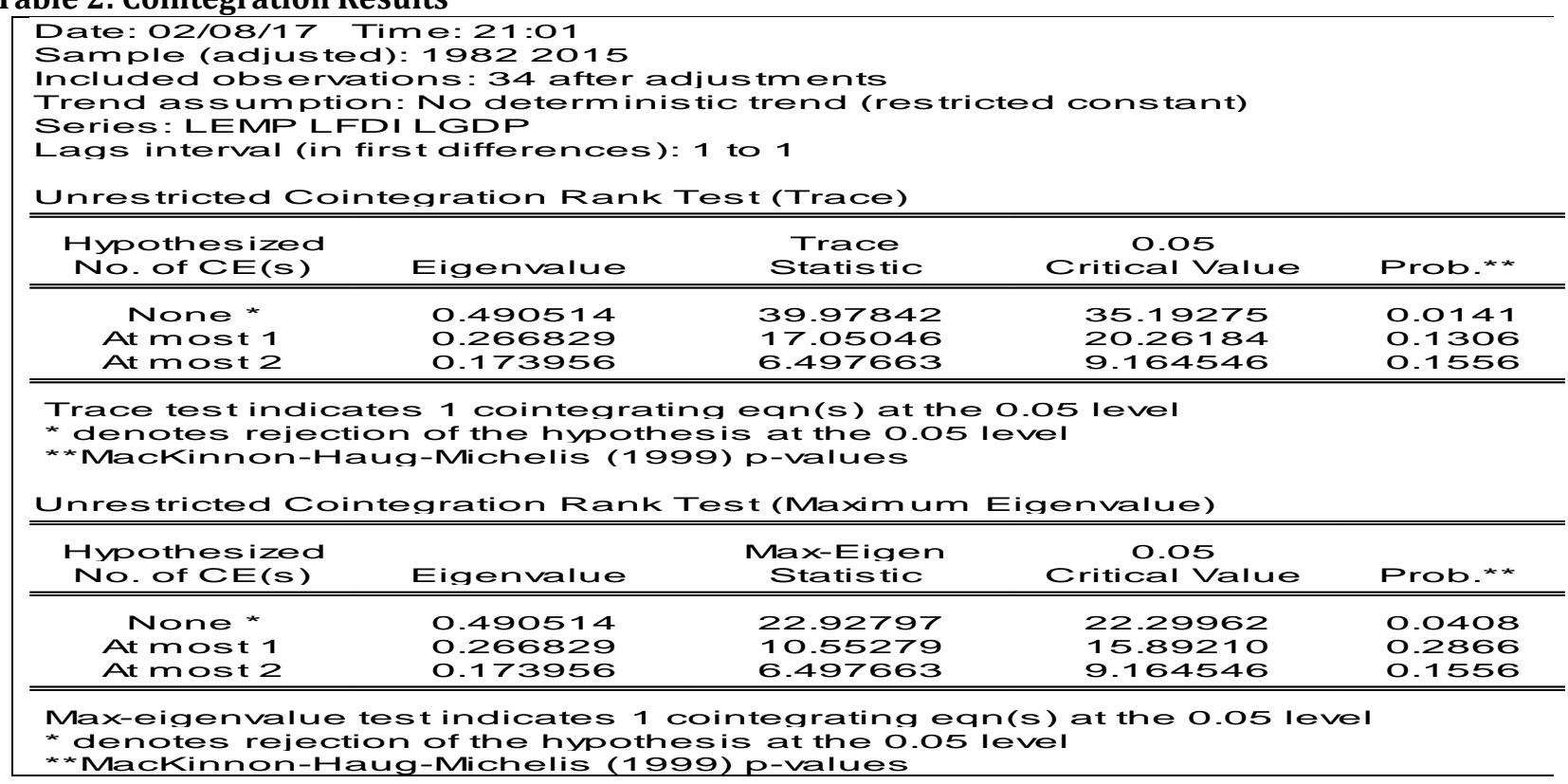

Source: Researcher's own results.

In the light of the model selection criterion, the FPE and AIC were employed when selecting a lag order within a second order VAR model since the data set is relatively small for this particular study. This procedure led to the selection of order $(\mathrm{p})=2$ through the use of FPE and AIC. Table 2 indicates that the null hypothesis of zero 
cointegrating vectors $(r=0)$ is rejected by both the trace $(39.98>35.19)$ and the maximum eigenvalue $(22.93$ $>22.30)$ tests, at the $0.05 \%$ significance level. The null hypothesis of almost one cointegrating vector $(r=1)$ cannot be rejected by these two tests since the trace statistic $(17.05<20.26)$ and the maximum eigenvalue $(10.55<15.90)$. The relationship of one cointegration vector is then estimated and reported in equation 9 , in the same pattern as $\beta_{12}$ and $\beta_{13}$ cointegration equation in equation 4 .

The VECM Long-Run Relationship and Short-Run Adjustment Coefficients: The estimated VECM short and long-run equation is presented as follows:

$$
\begin{aligned}
\Delta L E M P_{t}=-0.02 & \left(62.6+L E M P_{t-1}+0.64 L F D I_{t-1}-5.2 L G D P_{t-1}\right)+\mathbf{0 . 3 8} \Delta L E M P_{t-1}-\mathbf{0 . 1 3} \Delta L F D I_{t-1} \\
& +0.18 \Delta L G D P_{t-1}
\end{aligned}
$$

Cointegration results confirmed that variables are cointegrated and there is only one cointegrating vector in the system. The theory suggests that long-run coefficients of the VECM ought to be interpreted as an opposite sign due to the negative signs in the ECM equation. The long-run coefficient $\left(\beta_{12}\right)$ suggests that a $1 \%$ rise in FDI will cause employment to decrease by $0.64 \%$ per annum, statistically significant at $1 \%$. On the other hand, the elasticity of employment to GDP, $\beta_{13}(5.23)$ is of the correct positive sign and statistically significant at $5 \%$. This is plausible because a rise in GDP ought to lead to a significant increase in employment. These results support the "Jobless Growth" theory proposed by Ricardo (1821), which states that there is a negative relationship between investment, output expansion and job creation because capital investment is a perfect substitute for labour in the economy. The empirical evidence of a negative impact of FDI on employment levels has been reported by a number of global researchers, such as Pinn et al. (2011); Wei (2013) and Onimisi (2014).

Some of the possible reasons for FDI to have a negative effect on employment levels are that FDI may displace domestic investment in such a way that the net effect on employment is less than the number of people employed directly by FOEs. Pinn et al. (2011) suggested that when FDI involves the acquisition of domestic firms instead of establishing new enterprises, the domestic employment level will stay the same, and if the foreign investor rationalises the firm, employment levels are even more likely to decrease in the domestic labour market. Fedderke and Romm (2006) asserted that the nature of FDI is more capital-intensive than laborintensive and capital investment favors the employment of a few skilled workers. Hence, employment opportunities that are created may be for relatively skilled labour, rather than the unskilled labour that is in excess supply in the South African labour market. According to Pinn et al. (2011), FDI can decrease employment levels by withdrawing investments and shutting down local firms by imposing intense competition in the domestic market. Some of the worrying factors for South Africa include rigid labour market policies, militant labour unions and excessive unskilled labour, which makes it difficult for foreign investors to invest in laborintensive industries that will promote employment for unskilled labour market segment.

The Short-run Adjustments Coefficients: The VECM results reported -0.024 speed of adjustment, which means that employment is moving by $0.024 \%$ in the current year in order to adjust the long-run disequilibrium as a result of employment deviating from this equilibrium by $1 \%$ in the previous year. This error correction term makes economic sense because it indicates that there is no strong pressure on employment to restore long-run equilibrium whenever there is a disturbance in the system. The low speed of adjustment for employment may suggest that there are some other important factors that affect employment in South Africa, apart from FDI, which could be the level of education, labour costs, inflation and trade union rigidity, among others. The error correction term for LFDI is significant but possesses the incorrect sign, i.e., LFDI falls by $0.15 \%$ in this period as a result of LEMP overstepping its equilibrium in the previous period. Theoretically, it ought to adjust to equilibrium by increasing since it shares a negative long-run relationship with the dependent variable. However, the adjustment coefficient is very low and not destabilising to the long-run equilibrium relationship. The short-run adjustment of LGDP to a previous period overshooting of LEMP, relative to its long-run cointegrating relationship, has the correct negative sign and the magnitude of $0.017 \%$ is plausible. The Granger causality tests show that employment has a bi-directional causal relationship with FDI significant at 5\% significance level.

Single Equation Models: Single equations methods produced plausible results when employing all six variables in the model specification, whereas VAR/VECM produced plausible results when estimating the model using three main variables which include employment, FDI and GDP. 
The Ordinary Least Squares (OLS) Model Results: The OLS method seeks to examine the interaction between FDI, GDP, inflation rate, trade openness and labour cost on employment. The estimated OLS model results are as follows:

$$
\begin{aligned}
& L E M P=-\mathbf{6 . 7 0}-0.13 L F D I+\mathbf{0 . 6 5} L G D P+0.5 I N F-0.2 T O P+\mathbf{0 . 1 3} L L C \\
& {[-4.44] \quad[-4.31] \quad[4.92] \quad[1.62] \quad[-1.01] \quad[2.78]}
\end{aligned}
$$

A negative elasticity coefficient of FDI suggests that if FDI increases by $1 \%$, employment levels would decrease by $0.13 \%$ in the long-run. The results also suggest that employment responds positively due to an increase in GDP and inflation rates as suggested by economic theory. However, inflation and trade openness are both statistically insignificant to affect employment in the long-run. According to estimated results, labour cost also positively impact employment levels with $0.13 \%$, implying that if labour cost increases by $1 \%$, employment would rise by $0.13 \%$. On the other hand, trade openness has an inverse relationship with employment levels in the South African economy, implying that a $1 \%$ increase in trade openness would result to employment contracting by $0.2 \%$ in the long-run.

Fully Modified Ordinary Least Squares (FMOLS) Model: The FMOLS results are estimated with the nonprewhitened Barlett kernel, Newey-West fixed bandwidth $=40.000$ model. The estimated equation of the FMOLS is reported as follows:

$$
\begin{array}{ccccc}
L E M P=-\mathbf{1 8 . 6 6 - 0 . 1 6} L F D I+\mathbf{1 . 7 2} L G D P+\mathbf{1 . 0} I N F-\mathbf{1 . 0 T O P}+0.12 L L C \\
{[-9.10]} & {[-3.45]} & {[11.01]} & {[2.15]} & {[-2.91]}
\end{array}
$$

The results of a FMOLS model indicate that there is a significant negative long-run relationship between FDI and employment levels. The results suggest that a $1 \%$ rise in FDI causes employment to decrease by $0.16 \%$ in the long-run. A positive coefficient of GDP implies that a unitary increase in GDP leads to a $1.72 \%$ rise in employment levels, ceteris paribus. These elasticity coefficients are both statistically significant at $1 \%$ level of significance. As expected, inflation positively impacts on employment with the elasticity coefficient of 1.0. A negative coefficient of $-1.0 \%$ for trade openness suggests that a $1 \%$ rise in trade openness would result in a $1.0 \%$ decrease in employment. A positive coefficient of labour cost suggests that a $1 \%$ rise in labour cost would result in a $0.12 \%$ increase in employment levels.

However, the coefficient elasticity of trade openness is not theoretically plausible in the conventional sense because the more the country becomes open to trade, the more employment and growth transpires in the country. The major reason for this deviation from conventional theoretical perspectives concerning the negative impact of trade openness on employment could be as a result of cheap imports that are imported from countries with low economies of scale and cheap labour costs, which could result to a negative effect on domestic output levels, and thus employment. The coefficient result of labour cost is also not theoretically plausible, since it is expected that a rise in the cost of labour will correlate with a decrease in employment levels, and vice versa. The main reason could be that it is the cost of labour for skilled worker that is increasing, rather than unskilled labour, which is in excess supply in the South African labour market.

The Dynamic Ordinary Least Squares (DOLS) Model: The long-run equilibrium equation of the DOLS model is reported as follows:

$$
\begin{aligned}
& L E M P=-16.98-0.24 L F D I+1.61 L G D P+2.0 I N F-1.0 T O P+\mathbf{0 . 2 8} L L C
\end{aligned}
$$

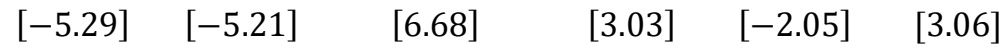

The results produced by the DOLS complement the results estimated by the FMOLS, and hence the VECM longrun estimates. The above equation (13) suggests that $1 \%$ rise in FDI causes employment to decrease by $0.24 \%$, ceteris paribus. The long-run positive coefficients for GDP, inflation and labour costs indicate that a $1 \%$ change in these variable would lead to a $1.61 \%, 2.0 \%$, and $0.28 \%$ increase in employment, respectively and all statistically insignificant at $1 \%$ level of significance. On the other hand, a negative coefficient of trade openness reveals that if trade openness increase by $1 \%$, employment would contract by $1.0 \%$. Moreover, there is a unidirectional causal relationship running from FDI to GDP at 5\% level of significance. There was no causal link observed between employment and GDP, which implies that these two variables are strongly exogenous to explain the movements in employment.

The Canonical Cointegration Regression (CCR) Model: The estimated CCR regression equation is reported as follow:

$L E M P=-18.25-0.16 L F D I+1.68 L G D P+1.0 I N F-1.0 T O P+0.13 L L C$ 


$$
[-8.98] \quad[-2.93] \quad[11.46] \quad[1.75] \quad[-2.80] \quad[1.30]
$$

The CCR results suggest that increasing FDI inflows by $1 \%$ would result in a $0.16 \%$ decrease in employment in the long-run at $1 \%$ level of significance, ceteris paribus. In contrast, a $1 \%$ increase in GDP, inflation and labour cost causes employment levels to rise by $1.68 \%, 1.0 \%$ and $0.13 \%$ at $1 \%, 10 \%$, and labour cost is insignificant to affect employment, respectively. Moreover, a negative coefficient of trade openness indicates that a $1 \%$ rise in trade openness would lead to employment to contract by $1.0 \%$. These results validate the results obtained from the VECM, OLS, FMOLS and DOLS.

Summary of the Empirical Results: This section gives the summary of the overall empirical results estimated by both multiple and single equation methods. Table 3 below presents the summarised results of both short and long-run coefficients for each variable affecting employment (LEMP) for the purpose of simplicity when discussing and comparing the empirical findings.

Table 3: Summary of Long-Run and Short-Run Relationships

\begin{tabular}{|c|c|c|c|c|c|c|}
\hline \multicolumn{7}{|c|}{ Sample Size 1985 to 2015 (Annual Data, i.e., 36 Observations) } \\
\hline \multirow[t]{3}{*}{ Variables } & \multicolumn{6}{|l|}{ VECM } \\
\hline & & & OLS & FMOLS & DOLS & CCR \\
\hline & SR & LR & & & & \\
\hline LEMP & $\begin{array}{c}0.38^{* *} \\
{[2.55]}\end{array}$ & - & - & - & - & - \\
\hline LFDI & $\begin{array}{l}-0.13^{* * *} \\
{[-3.26]}\end{array}$ & $\begin{array}{l}-0.64^{* * *} \\
{[2.18]}\end{array}$ & $\begin{array}{l}-0.13^{* * *} \\
{[-4.31]}\end{array}$ & $\begin{array}{l}-0.16^{* * *} \\
{[-3.50]}\end{array}$ & $\begin{array}{l}-0.24 * * * \\
{[-5.21]}\end{array}$ & $\begin{array}{l}-0.16^{* * *} \\
{[-2.93]}\end{array}$ \\
\hline LGDP & $\begin{array}{l}0.18 \\
{[0.56]}\end{array}$ & $\begin{array}{l}5.21 * * \\
{[-2.88]}\end{array}$ & $\begin{array}{l}0.65^{* * *} \\
{[4.92]}\end{array}$ & $\begin{array}{c}1.72^{* * *} \\
{[11.01]}\end{array}$ & $\begin{array}{l}1.61^{* * *} \\
{[6.68]}\end{array}$ & $\begin{array}{c}1.68^{* * *} \\
{[11.46]}\end{array}$ \\
\hline INF & - & - & $\begin{array}{l}0.5 \\
{[1.62]}\end{array}$ & $\begin{array}{l}1.0^{* *} \\
{[2.15]}\end{array}$ & $\begin{array}{c}2.0 * * \\
{[3.03]}\end{array}$ & $\begin{array}{l}1.0^{*} \\
{[1.75]}\end{array}$ \\
\hline TOP & - & - & $\begin{array}{l}-0.2 \\
{[-1.01]}\end{array}$ & $\begin{array}{l}-1.0 * * * \\
{[-2.91]}\end{array}$ & $\begin{array}{l}-1.0^{*} \\
{[-2.05]}\end{array}$ & $\begin{array}{l}-1.0 * * * \\
{[-2.80]}\end{array}$ \\
\hline LLC & - & - & $\begin{array}{l}0.13^{* * *} \\
{[2.78]}\end{array}$ & $\begin{array}{l}0.12 \\
{[1.55]}\end{array}$ & $\begin{array}{l}0.28^{* * *} \\
{[3.06]}\end{array}$ & $\begin{array}{l}0.13 \\
{[1.30]}\end{array}$ \\
\hline
\end{tabular}

Notes: SR and LR denote short-run and long-run, respectively. T-statistics are shown in parenthesis [ ]. ${ }^{* * *}$, **and ${ }^{*}$ indicate statistical significance level at $1 \%, 5 \%$ and $10 \%$ respectively.

The summary of results for VECM, FMOLS, DOLS and CCR methods provide evidence of a long-run cointegrating relationship between employed variables in both single and systems of equations. These empirical findings clearly demonstrate that the effect of FDI on employment levels in the South African economy is negative and highly significant at 1\% significance level in both short and long-run relationship in all models under consideration. The results for both system and single equation models generate a negative short and long-run coefficient capturing the impact of FDI on employment. The short-run coefficients of FDI estimated by the VECM and OLS model are $-0.13 \%$ for both models significant at $1 \%$ level of significance. The empirical findings of this study are plausible and make economic sense because all models that were estimated produced coefficients that point in the same direction in the long-run. In the long-run, multiple and single equation methods complement one another, suggesting that the FDI negatively and significantly affect employment and its longrun coefficients range across the following spectrum under VECM, FMOLS, DOLS and CCR respectively: $-0.64 \%$, $-0.16 \%,-0.24 \%$ and $-16 \%$. These are all significant at $1 \%$ level of significance. The OLS model shows that if FDI increases by $1 \%$, employment will fall by $0.13 \%$, significant at $1 \%$ level of significance in the long-run. Hence, all models that test for a long-run co-integrating relationship suggest that FDI has a negative and statistically significant impact on employment levels in the long-run in the economy of South Africa. The VECM results reveal that if FDI increases by $1 \%$, then employment levels would contract by $0.64 \%$ in the long-run.

The FMOLS, DOLS and CCR results suggest that a $1 \%$ rise in FDI would lead to a $0.16 \%, 0.24 \%$, and $0.16 \%$ fall in employment level in the long-run, respectively. These findings are consistent with the empirical literature 
conducted in the same subject area as shown in the work of Jenkins, (2006), Wei (2013) and Onimisi, (2014), among others. The long-run coefficient elasticity of LGDP indicates that GDP plays a very important role in increasing employment levels in South Africa's economy. The estimated results of the VECM, FMOLS, DOLS and CCR suggest that if GDP rises by 1\%, employment levels will increase by $5.21 \%, 1.72 \%, 1.61 \%$, and $1.68 \%$, at $5 \%$ and $1 \%$ level of significance, respectively. This finding is in line with economic theory and empirical evidence presented by prior studies on the same subject. Two of the six variables inflation and labour costs also have a positive impact on employment in the long-run, as only suggested by single co-integrating regression equations, i.e. FMOLS, DOLS, and CCR model, since the VECM only estimates the interaction between employment, FDI and GDP. The elasticity magnitude of inflation ranges from $1.0 \%, 2.0 \%$ and $1.0 \%$ significant at $5 \%$ for FMOLS and DOLS, and significant at 10\% for CCR, respectively. The coefficients for labour costs are $0.12 \%, 0.28 \%$ and $0.13 \%$ under FMOLS, DOLS, and CCR respectively, and only DOLS coefficient is significant. On the other hand, co-integrating regression equations found that trade openness was negative and statistically insignificant to affect employment levels in the long-run.

The coefficients' magnitudes of trade openness are $-1.0 \%$ for all three single co-integrating regression equation (FMOLS, DOLS, and CCR) at 1\%, 10\% and $1 \%$ level of significance, respectively. This implies that a $1 \%$ increase in trade openness would lead to a $1.0 \%$ decline in employment. The OLS coefficient for trade openness was also found to be negative but statistically insignificant in its influence on employment. OLS results suggest that a $1 \%$ rise in trade openness would lead to a $0.2 \%$ decrease in employment. This finding also conflicts with the findings of prior studies. However, the economic reasoning behind this relationship could be that our major trading partners are providing cheap imports, which could lead to a negative impact on domestic output levels and thus employment. The single-equation model (OLS, FMOLS, DOLS, and CCR) provides results that are consistent with those of the VECM method in all cases, with respect to both short and long-run coefficients of employment, FDI and GDP. The magnitudes of the coefficients of variables tend to vary closely between the VECM multi-equation approach and the single equation models. The implication of negative short and long-run coefficient estimates is that FDI cannot be used to promote employment levels in the economy, but they could be good for growth and other development objectives of the country. These empirical findings suggest that FDI inflows lead to a jobless growth in the South African economy, as suggested by Ricardo (1821) in the "Jobless growth" theory.

\section{Conclusion}

The empirical results from both systems (VAR/VECM) and single (OLS, FMOLS, DOLS, and CCR) equations models reveal that FDI inflows result to contraction of employment levels in both short and long-run outlook of the South African economy. Studies carried out by Wei (2013) and Onimisi (2014) also came to the same conclusion that FDI has a negative effect on employment. The findings are also in line with the "Jobless Growth" theory formulated by Ricardo (1821) which states that there is a negative relationship between investment, output expansion, and job creation because capital investment is a perfect substitute for labour in the economy. The results are also supported by scientific literature which suggests that FDI are more capital-intensive and therefore tend to sacrifice labor-intensive employment opportunities. The study recommends that it is imperative for South Africa to continue to promote policies that aim to attract FDI for the purpose of improving other macroeconomic developmental objectives that will create job opportunities to help reduce a high unemployment rate, and also to develop a social compact with trade unions to accept lower wages for the unskilled labor market segment, so that appropriate FDI targeting labor-intensive industries becomes viable. This could be done through special economic zones that make it particularly attractive for low-wage, highly labor-intensive investment projects to flourish in South Africa.

\section{References}

Asteriou, D. \& Hall, S. G. (2016). Applied Econometrics: A Modern Approach Using Eviews and Microfit. New York, Palgrave Macmillan.

Bailey, D. \& Driffield, N. (2007). Industrial Policy, FDI, and Employment: Still Missing a Strategy. Journal of Industry, Competition and Trade, 7(3-4), 189-211.

Belke, A. \& Czudaj, R. (2010). Is euro area money demand (still) stable? Co-integrated VAR versus single equation techniques. Applied Economics Quarterly, 56(4), 285-315. 
Brooks, C. (2014). Introductory Econometrics for Finance, 2nd Edition. New York, Cambridge University Press.

Carp, L. (2012). Analysis of the Relationship between FDI and economic growth - Literature Review Study. The USV Annals of Economics and Public Administration, 12(15), 154-160.

Das, B. K. (2007). Theories of Foreign Direct Investment. Gauhati University.

Denisia, V. (2010). Foreign direct investment theories: An overview of the main FDI theories. The European Journal of Interdisciplinary Studies, 2(3).

Department of Trade and Industry. (2015). [Online] Available from: http://www.thedti.gov.za/. [Accessed on 17/01/2017].

Engle, R. F. \& Granger, C. W. J. (1987). Co-integration and Error Correction: Representation, Estimation, and Testing. Econometrica, 55(2), 251-276.

Fedderke, J. W. \& Romm, A. T. (2006). Growth impact and determinants of foreign direct investment into South Africa, 1956-2003. Economic Modelling, 23(5), 738-760.

Harris, R. \& Sollis R. (2003). Applied time series modeling and forecasting. International Journal of Forecasting. Wiley.

Huang, M. \& Ren, P. (2013). A study on the employment effect of Chinese investment in South Africa. Discussion Papers (Centre for Chinese Studies). Available at http://www.sun.ac.za/ccs.

Inekwe, J. N. (2013). FDI, Employment and Economic Growth in Nigeria. African Development Review, 25(4), 421-433.

Jenkins, C. \& Thomas, L. (2002). Foreign direct investment in Southern Africa: determinants, characteristics, and implications for economic growth and poverty alleviation. CSAE, University of Oxford.

Jenkins, R. (2006). Globalization, FDI and Employment in Vietnam. Transnational Corporations, 15(1), 115-142.

Johansen, S. (1991). Estimation and Hypothesis Testing of Co-integrating Vectors in Gaussian Vector Autoregressive Models. Econometrica, 59(1), 1551-1580.

Khatodia, N. \& Dhankar, R. S. (2016). Foreign Capital Inflows and Growth of Employment in India: An Empirical Evidence from Public and Private Sector. International Journal of Economics and Finance, 8(2), 189.

Makino, S. \& Tsang, E. W. (2011). Historical ties and foreign direct investment: An exploratory study. Journal of International Business Studies, 42(4), 545-557.

Montalvo, J. G. (1995). Comparing co-integrating regression estimators: Some additional Monte Carlo results. Economics Letters, 48(3) 229-234.

Mpanju, A. K. (2012). The impact of foreign direct investment on employment creation in Tanzania. ENITH International Journal of Business Economics and Management Research, 2(1), 126-139.

Okoro, H. M. \& Johnson A. A. (2014). Impact of Foreign Direct Investment on Employment Generation in Nigeria: A Statistical Investigation. IOSR Journal of Business and Management, 16(3), 44-56.

Onimisi, A. T. (2014). Foreign Direct Investments and Employment Generation Nexus in Nigeria. Journal of Educational and Social Research, 4(5), 119.

Phillips, P. \& Hansen B. (1990). Statistical inference in instrumental variables regression with 1(1) processes. Review of Economic Studies, 57, 99-125.

Pinn, S. L. S., Ching, K. S., Kogid, M., Mulok, D., Mansur, K. \& Loganathan, N. (2011). Empirical analysis of employment and foreign direct investment in Malaysia: An ARDL bounds testing approach to cointegration. Advances in Management and Applied Economics, 1(3), 77-91.

Ricardo, D. (1821). On the Principles of Political Economy and Taxation. In: P. Sraffa. Vol.1. The Works and Correspondence of David Ricardo. Cambridge University Press, 1970.

Romer, P. M. (1994). The origins of endogenous growth. The journal of economic perspectives, 8(1), 3-22.

Saayman, M. \& Rossouw, R. (2010). The economic value of the 2010 Soccer World Cup Safety and Security Sector Education and Training Authority. Sector Skills Plan, 2012-2013 update.

Shakar, S. A. \& Aslam, M. (2015). Foreign direct investment, human capital and economic growth in Malaysia. Journal of Economics Cooper, Dev, 36(1), 103-132.

Sims, C. A. (1980). Macroeconomics and reality. Econometrica, 48, 1-49.

Stock, J. \& Watson, M. (1993). A simple estimator of cointegrating vectors in higher order integrated systems. Econometrica, 61(4), 783-820.

Sunde, T. (2017). Foreign direct investment, exports, and economic growth: ADRL and causality analysis for South Africa. Research in International Business and Finance, 41, 434-444.

Tshepo, M. (2014). The Impact of Foreign Direct Investment on Economic Growth and Employment in South Africa: A Time Series Analysis. Mediterranean Journal of Social Sciences, 5(25), 18. 
Vernon, R. (1966). International investment and international trade in the product cycle. Quarterly Journal of Economics, 80, 190-207.

Wei, Y. (2013). The effect of FDI on employment in China. Graduate Theses and Dissertations Paper 13379.

\begin{tabular}{|c|c|c|c|}
\hline \multicolumn{4}{|c|}{$\begin{array}{l}\text { Vector Error Correction Estimates } \\
\text { Date: 02/08/17 Time: } 21: 03 \\
\text { Sample (adjusted): } 19822015 \\
\text { Included observations: } 34 \text { after adjustments } \\
\text { Standarderrors in () \& t-statistics in [ ] }\end{array}$} \\
\hline Cointegrating Eq: & CointEq 1 & & \\
\hline LEMP(-1) & 1.000000 & & \\
\hline LFDI(-1) & $\begin{array}{l}0.638470 \\
(0.29246) \\
{[2.18314]}\end{array}$ & & \\
\hline LGDP(-1) & $\begin{array}{r}-5.217160 \\
(1.81103) \\
{[-2.88077]}\end{array}$ & & \\
\hline C & $\begin{array}{r}62.63943 \\
(22.9595) \\
{[2.72826]}\end{array}$ & & \\
\hline Error Correction: & D(LEMP) & $D(L F D I)$ & $D(L G D P)$ \\
\hline CointEq1 & $\begin{array}{r}-0.024308 \\
(0.00921) \\
{[-2.63933]}\end{array}$ & $\begin{array}{r}-0.149597 \\
(0.03812) \\
{[-3.92415]}\end{array}$ & $\begin{array}{r}-0.016949 \\
(0.00554) \\
{[-3.06127]}\end{array}$ \\
\hline$D(L E M P(-1))$ & $\begin{array}{l}0.381655 \\
(0.14981) \\
{[2.54766]}\end{array}$ & $\begin{array}{r}-0.187462 \\
(0.62008) \\
{[-0.30232]}\end{array}$ & $\begin{array}{r}-0.001161 \\
(0.09006) \\
{[-0.01289]}\end{array}$ \\
\hline$D($ LFDI(-1)) & $\begin{array}{r}-0.134343 \\
(0.04117) \\
{[-3.26326]}\end{array}$ & $\begin{array}{r}0.154786 \\
(0.17040) \\
{[0.90835]}\end{array}$ & $\begin{array}{r}-0.041877 \\
(0.02475) \\
{[-1.69206]}\end{array}$ \\
\hline$D($ LGDP(-1)) & $\begin{array}{r}0.181374 \\
(0.32212) \\
{[0.56306]}\end{array}$ & $\begin{array}{r}-1.276555 \\
(1.33332) \\
{[-0.95742]}\end{array}$ & $\begin{array}{r}0.281131 \\
(0.19365) \\
{[1.45177]}\end{array}$ \\
\hline $\begin{array}{l}\text { R-squared } \\
\text { Adj. R-squared } \\
\text { Sum sq-resids } \\
\text { S.E. equation } \\
\text { F-statistic } \\
\text { Loglikelihood } \\
\text { Akaike AlC } \\
\text { SchwarzSO } \\
\text { Mean dependent } \\
\text { S.D. dependent }\end{array}$ & $\begin{array}{l}0.490297 \\
0.439327 \\
0.037295 \\
0.035259 \\
9.619287 \\
67.61525 \\
-3.742074 \\
-3.562502 \\
0.015992 \\
0.047088 \\
\end{array}$ & $\begin{array}{l}0.162308 \\
0.078539 \\
0.638984 \\
0.145943 \\
1.937567 \\
19.31811 \\
-0.901065 \\
-0.721494 \\
0.177272 \\
0.152036 \\
\end{array}$ & $\begin{array}{r}0.124363 \\
0.036799 \\
0.013479 \\
0.021196 \\
1.420254 \\
84.91735 \\
-4.759844 \\
-4.580272 \\
0.021313 \\
0.021597\end{array}$ \\
\hline $\begin{array}{l}\text { Determinant resid cov } \\
\text { Determinant resid cov } \\
\text { Log likelihood } \\
\text { Akaike information crit } \\
\text { Schwarz criterion }\end{array}$ & $e^{e}($ dof $\operatorname{adj})$. & $\begin{array}{r}1.07 E-O 8 \\
7.35 E-09 \\
173.6580 \\
-9.274000 \\
-8.555713\end{array}$ & \\
\hline
\end{tabular}

